\title{
Perspektif Bisnis Syariah Pada Jasa Transportasi Online Go-Jek di Makassar
}

\author{
Abd. Rizal, Amiruddin K., Mirwan Misbach \\ Universitas Islam Negeri Alauddin Makassar \\ Jln. HM. Yasin Limpo No.36, Romangpolong, Gowa \\ Email: abdrizal.alistiqamah@gmail.com \\ Diterima: 31 Desember 2019; Direvisi: 9 Juli 2020 Diterbitkan: 12 Juli 2020
}

\begin{abstract}
Abstrak,
Penelitian ini bertujuan untuk mengidentifikasi layanan transportasi online terhadap konsumen dan ojek pangkalan, serta kaitannya dengan perspektif bisnis syariah pada jasa transportasi online Go-Jek. Penelitian ini termasuk dalam kategori penelitian kualitatif dengan pendekatan fenomenologi dan normatif. Hasil penelitian menunjukkan bahwa, dalam pandangan pengemudi ojek pangkalan, kehadiran jasa transportasi online Go-Jek berdampak pada penurunan pendapatan pengemudi ojek pangkalan. Sedangkan bagi konsumen, kehadiran ojek online Go-Jek memberikan manfaat dan kemudahan dengan berbagai jenis layanannya. Adapun perspektif bisnis syariah dari jasa transportasi online Go-Jek secara umum dinilai telah menjalankan konsep bisnis syariah yang terdiri dari prinsip dasar bisnis syariah, etika bisnis syariah dan tujuan bisnis syariah.
\end{abstract}

Kata Kunci: Ojek Pangkalan, Ojek Online, Bisnis Syariah

\begin{abstract}
,
This study aims to identify online transportation services for consumers and base taxis, as well as their relationship with sharia business perspective on Go-Jek online transportation services. This research belongs to the category of qualitative research with a phenomenological and normative approach. The results showed that, in the view of base taxi drivers, the presence of Go-Jek online transportation services had an impact on the decline in base taxi driver income. As for consumers, the presence of Go-Jek online motorcycle taxi provides benefits and convenience with various types of services. The sharia business perspective of the Go-Jek online transportation service generally considered to have run a sharia business concept that consists of basic sharia business principles, sharia business ethics, and sharia business objectives.
\end{abstract}

Keywords: Conventional Ojek, Online Ojek, Sharia Business 


\section{PENDAHULUAN}

Islam merupakan ajaran Allah yang bersifat universal yang mengatur seluruh aspek kehidupan manusia. Manusia sebagai makhluk sosial dalam memenuhi kebutuhan hidupnya, baik secara material maupun spiritual, selalu berhubungan antara yang satu dengan yang lain (Ismail Nawawi, 2012). Manusia saling tukar menukar manfaat di semua aspek kehidupan, baik melalui bisnis atau jual beli, sewa menyewa, bekerja dalam bidang pertanian, industri, jasa maupun bidang lainnya. Semua itu membuat manusia berinteraksi, bersatu, berorganisasi, dan saling bantu membantu dalam memenuhi kebutuhannya (Yusuf Qardawi, 2005).

Manusia di era globalisasi lebih mengedepankan sistem ekonomi yang cenderung ke arah sistem ekonomi yang tidak sesuai dengan konsep bisnis syariah, seperti melakukan praktik yang mengandung unsur al-batil (kebatilan), al-fasad (kerusakan) dan al-zalim (kezaliman) terhadap orang lain ataupun pesaing bisnisnya ataupun kegiatan bisnis yang memiliki kemudharatan lebih besar dibandingkan dengan kemaslahatannya yang dalam konsep bisnis syariah hal tersebut merupakan praktik yang terlarang dan tidak dibolehkan. Oleh sebab itu, sebagai umat Islam seharusnya tetap memegang teguh nilai-nilai Islam dalam hal apapun agar mendapat berkah dari kegiatan yang dilakukan termasuk dalam berbisnis seperti dalam QS al-Taubah/9: 105 .
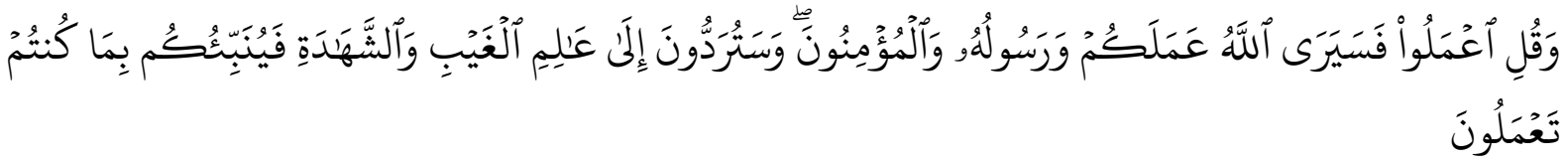

Terjemhanya:

Dan Katakanlah: Bekerjalah kamu, maka Allah dan Rasul-Nya serta orang-orang mukmin akan melihat pekerjaanmu itu, dan kamu akan dikembalikan kepada (Allah) Yang Mengetahui akan yang ghaib dan yang nyata, lalu diberitakan-Nya kepada kamu apa yang telah kamu kerjakan.

Oleh karena itu, setiap pelaku bisnis khususnya para pebisnis muslim diwajibkan memahami konsep bisnis syariah (Binhadi, dkk., 2011), antara lain: prinsip dasar bisnis syariah yaitu prinsip dasar halal dan baik, praktik yang terlarang dalam bisnis Syariah, etika dalam persaingan bisnis Syariah dan tujuan bisnis syariah. Allah memerintahkan hambanya untuk mencari rezeki yang halal dan baik, Allah berfiman dalam QS al-Baqarah/2: 168.

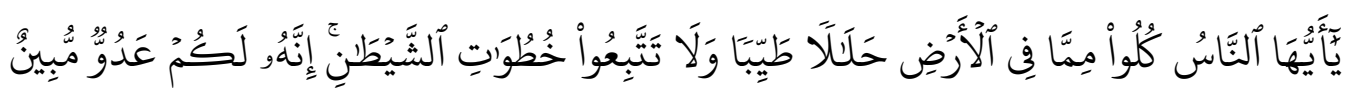

Terjemahnya:

Wahai manusia, makanlah yang halal lagi baik dari apa yang terdapat di bumi, dan janganlah kamu mengikuti langkah-langkah syaitan karena sesungguhnya syaitan itu adalah musuh yang nyata bagimu. 
Berdasarkan ayat tersebut, bahwa prinsip halal dan baik ini menyangkut terkait dengan produk barang, jasa maupun proses kegiatannya. Makna tayyib memiliki pengertian yang mencakup segala nilai-nilai kebaikan yang menjadi nilai tambah dari hal-hal yang halal dalam rangka pencapaian tujuan bisnis syariah yaitu memperoleh keuntungan material dan non material, mendorong terjadinya pertumbuhan ekonomi, menjaga keberlangsungan bisnis dan memperoleh berkah dan rida Allah.

Salah satu kegiatan bisnis yang akhir-akhir ini menjadi menjadi fenomena atau viral yaitu bisnis jasa transportasi online yang dinamakan Go-Jek yang kemudian banyak digunakan oleh masyarakat. Dengan adanya jasa transportasi online Go-Jek yang dapat memudahkan bagi pengguna jasa transportasi dalam menggunakannya, baik dari segi cara pemesanannya, harga jasa angkutannya maupun cara pembayarannya yang kemudian banyak masyarakat yang pada awalnya menggunakan jasa transportasi konvensional (ojek pangkalan) beralih menggunakan jasa transportasi ojek online yaitu Go-Jek.

Go-Jek adalah sebuah perusahaan teknologi berjiwa sosial yang bertujuan untuk meningkatkan kesejahteraan pekerja di berbagai sektor informal di Indonesia. Kegiatan GoJek bertumpu pada 3 nilai pokok: kecepatan, inovasi, dan dampak sosial. Bermula di tahun 2010 sebagai perusahaan transportasi roda dua melalui panggilan telepon, Go-Jek kini telah berkembang menjadisalah satu penyedia jasa transportasi online terdepan yang menyediakan berbagai layanan lengkap mulai dari jasa angkutan, logistik, pembayaran, layanan antar makanan, dan berbagai layanan lainnnya yang disediakan oleh perusahaan GoJek, akan tetapi dalam proses perkembangan jasa transportasi online dengan berbagai layanan yang telah diberikan baik sebagai pengguna atau penumpang jasa ataupun sebagai pengemudi ojek, menyebabkan fenomena terjadinya peralihan penggunaan jasa transportasi ojek pangkalan ke jasa transportasi online sehingga terkadang memicu terjadinya konflik atau perselisihan di antara pengemudi jasa layanan transportasi ojek pangkalan (seperti bentor, dan ojek pangkalan) dengan pengemudi jasa transportasi ojek online dan juga sering terjadi aksi penolakan dan demonstrasi yang dilakukan oleh para pengemudi transportasi ojek pangkalan dan bahkan yang lebih parah lagi terkadang terjadi aksi penghadangan terhadap pengemudi ojek online yang dilakukan oleh pengemudi ojek pangkalan seperti yang dirilis dalam berita online yang menyebutkan tentang kisruh antara pengemudi ojek online dan ojek pangkalan di Makassar kembali terjadi. Perselisihan tersebut merupakan lanjutan kasus sebelumnya yang terjadi wilayah tamalanrea Makassar. Ada beberapa alasan penyebab terjadi perselisihan tersebut, yaitu alasan penyebab yang pertama adalah para pengemudi ojek pangkalan menganggap bahwa para pengemudi ojek online mengambil hak jasa angkutan ojek pangkalan dalam mencari atau menunggu penumpang yang kemudian menyebabkan jasa 
transportasi ojek pangkalan mengalami penurunan omset pendapatan yang dikarenakan oleh berkurangnya pengguna ojek pangkalan yang telah beralih ke jasa transportasi online Go-jek. Alasan kedua adalah transportasi ojek pangkalan mempermasalahkan cara penjemputan penumpang yang dilakukan jasa transportasi ojek online, pengemudi ojek pangkalan yang merasa dirugikan dengan adanya ojek online yang sering mengambil penumpang di wilayah tempat pangkalan bentor dan ojek.

Alasan ketiga adalah jasa transportasi ojek online dinilai telah memasang tarif yang dianggap jauh lebih murah daripada jasa transportasi ojek pangkalan. Sehingga dapat mempengaruhi omset pendapatan jasa transportasi ojek pangkalan. Para pengemudi ojek pangkalan menilai jasa transportasi berbasis aplikasi online telah memonopoli harga. Oleh karena itu, penumpang lebih memilih menggunakan jasa transportasi ojek online dibandingkan jasa transportasi ojek pangkalan karena harga atau jasa transportasi lebih murah dibandingkan dengan jasa transportasi ojek pangkalan.

Oleh sebab itu, setiap kegiatan bisnis yang dilakukan, diharapkan pelaku bisnis harus memahami dan melihat perkembangan zaman yaitu termasuk perkembangan tekonogi dan setiap pelaku bisnis khususnya pebisnis Muslim harus memahami konsep bisnis syariah yang terdiri dari prinsip dasar halal dan baik, etika bisnis syariah dan tujuan bisnis syariah, sehingga tidak terjadi perselisihan di antara pelaku bisnis jasa transportasi.

\section{TINJAUAN TEORITIK \\ Konsep Bisnis Syariah}

Sumber-sumber hukum bisnis syariah adalah Al-Qur'an, hadis dan ijtihad. Bisnis syariah terdiri dari dua unsur kata yaitu bisnis dan syariah. Bisnis merupakan segala sesuatu yang berkaitan dengan jual beli atau istilah sederhananya adalah kegiatan berdagang atau berniaga (Irwan Misbach, 2017). Kata bisnis dalam al-Qur'an biasanya yang digunakan dengan istilah at-tijarah, al-bai, tada'yantum, dan isytara yang secara umum berarti berniaga atau berdagang. Pengertian bisnis secara umum adalah sebagai suatu aktivitas yang dilakukan seseorang untuk memperoleh pendapatan atau penghasilan guna memenuhi kebutuhan hidupnya (Asmuni dan Siti Mujiatun, 2016). Adapun bisnis yang dimaksud dalam penelitian ini adalah bisnis jasa angkutan.

Syariah berasal dari bahasa arab "syara " atau "syari"at" yang berarti the moslem law atau hukum Islam. Syariah juga berarti prilaku yang terkait dengan niali-nilai keimanan dan ketauhidan (Asmuni dan Siti Mujiatun, 2016). Secara etimologis atau bahasa, Syariah adalah jalan ke tempat pengairan, atau jalan yang harus diikuti, atau tempat lalu air sungai. 
Berdasarkan pengertian tersebut, sehingga dapat disimpulkan bahwa bisnis syariah adalah serangkaian aktivitas jual beli dalam berbagai bentuknya yang tidak dibatasi jumlah kepemilikan hartanya baik barang atau jasa, tetapi dibatasi cara memperoleh dan menggunakannya, sehingga dalam mendapatkan harta dan menggunakannya tidak boleh dengan cara-cara yang diharamkan Allah swt. Oleh karena itu, berbisnis menurut ketentuan syariah tidak boleh bebas dari ketentuan syariat dan harus dibedakan antara halal dan haram atau yang hak dan yang batil tidak boleh dicampuradukkan.

Allah berfirman dalam QS al-Baqarah/2: 42.

Terjemahnya:

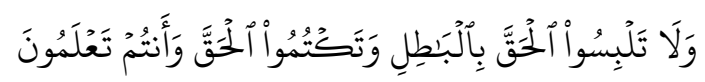

Dan janganlah kamu campuradukkan kebenaran dengan kebatilan dan (janganlah) kamu sembunyikan kebenaran, sedangkan kamu mengetahuinya.

Berdasarkan ayat di atas, maka bisnis menurut ketentuan syari'ah tidak boleh bersifat bebas, tetapi harus mengikuti prinsip halal dan haram bahkan yang syubhat lebih baik dijauhi daripada dilakukan.

Dalam buku pedoman umum good governance bisnis syariah, menjelaskan tentang dua prinsip dasar bisnis syariah yaitu prinsip dasar halal dan baik (Binhadi dkk, 2011). Sedangkan dalam berbagai kegiatan ekonomi yang dilakukan oleh perusahaan atau individu dengan tujuan tertentu, demikian pula dengan kegiatan ekonomi yang berbasis bisnis syariah yang juga mempunyai tujuan yang akan dicapai yaitu memperoleh keuntungan material dan non material, mendorong terjadinya pertumbuhan ekonomi, menjaga keberlangsungan bisnis, memperoleh berkah dan rida allah dan memperhatikan etika bisnis syariah.

Etika bisnis syariah merupakan acuan moral sebagai bagian dari wujud akhlaqul karimah dalam bisnis berbasis syariah. Etika bisnis syariah didasarkan pada itikad baik dan sikap saling rida antar pihak dengan tetap mentaati aspek halal dan baik (Binhadi dkk, 2011). Penerapan etika dalam bisnis syariah secara berkesinambungan akan menciptakan suasana yang kondusif bagi pembentukan budaya bisnis yang islami. Implementasi etika bisnis syariah dalam kegiatan bisnis tersebut akan tercapai jika telah memenuhi prinsip-prinsip etika bisnis syariah seperti yang telah dicontohkan oleh Rasulullah saw yaitu: customer oriented (kepuasan pelangga), transparansi, persaingan yang sehat, dan fairness (keadilan) (Norvadewi, 2015).

\section{Konsep Jasa Transportasi (Angkutan)}

Istilah transportasi atau sering juga disebut dengan istilah angkutan berasal dari kata angkut atau mengangkut yang berarti mengangkat, membawa, memuat, atau mengirimkan 
(Hoetomo, 2005). Menurut Undang-Undang Republik Indonesia Nomor 74 tentang Angkutan Jalan, Pasal 3 tentang Lalu Lintas dan Angkutan Jalan menyebutkan bahwa angkutan adalah perpindahan orang dan/atau barang dari satu tempat ke tempat lain dengan menggunakan kendaraan di ruang lalu lintas jalan atau dengan menggunakan kendaraan bermotor umum atau angkutan umum. Kendaraan bermotor sebagaimana dimaksud dalam Undang-Undang Republik Indonesia tentang Lalu Lintas dan Angkutan Jalan Angkutan orang dengan menggunakan kendaraan bermotor sebagaimana dimaksud dalam Pasal 3 ayat 1 huruf a berupa sepeda motor, mobil penumpang, atau mobil bus.

Istilah ojek dalam kamus bahasa indonesia disebut sebagai sepeda motor yang digunakan dengan cara membonceng atau mengantar penumpang dan penyewanya memberikan bayaran sebagai uang jasa angkutan (Hoetomo, 2005). Ojek pangkalan terdiri dari ojek dua roda dan ojek tiga roda (bentor). Dalam hal promosi ojek pangkalan, biasanya para pengemudi ojek pangkalan menggunakan atau memakai papan, triplek atau spanduk dipinggir jalan dengan membuat pangkalan sendiri dan biasanya jika pengemudi ojek pangkalan sudah terkenal akan direkomendasikan ke tetangga dan semua itu tergantung dari kepercayaan saja. Jadi, penumpang terlebih dahulu mendatangi pangkalan ojek atau hanya menunggu di tempat atau rumah calon penumpang dan berharap ojek pangkalan lewat dan menghampirinya. Untuk tarif jasa angkutannya terkadang bervariasi, hal tersebut tergantung atau ditentukan dengan tawar-menawar dengan pengemudi atau sopir terlebih dahulu, setelah tawar-menawar mengenai tarif jasa angkutan selesai dan disepakati, kemudian pengemudi akan mengantar penumpangnya sesuai dengan tujuan yang diinginkan.

Sedangkan ojek online disebut juga sebagai jasa transportasi yang menggunakan aplikasi online yang disediakan oleh penyedia jasa transportasi yang dapat di instal di smartphone pengguna dengan bantuan jaringan internet sebagai penghubung yang dapat mempermudah pemesanan, selain itu juga tarif perjalanan sudah dapat langsung dilihat pada aplikasi. Salah satu jasa transportasi ojek online yang sedang beroperasi saat ini adalah jasa transportasi online Go-Jek. Go-Jek yaitu sebuah perusahaan teknologi berjiwa sosial yang bertujuan untuk meningkatkan kesejahteraan pekerja dan pelayanan kepada masyarakat melalui jasa transportasi online di berbagai sektor informal di Indonesia.

\section{METODE PENELITIAN}

\section{Jenis dan Pendekatan Penelitian}

Jenis penelitian yang digunakan adalah penelitian kualitatif dengan pendekatan fenomenologi dan pendekatan normatif dengan mengunakan metode penelitian deskriptif analisis. Dalam hal ini, peneliti menghimpun data berkenaan dengan konsep, fenomena atau 
peristiwa, pendapat, pendirian sikap, penilaian dan pemberian makna terhadap situasi tertentu atau pengalaman dalam kehidupan. Sehingga data yang didapatkan di lapangan yang berkaitan dengan jasa transportasi ojek pangkalan dan ojek online dideskripsikan, diinterpretasikan, dianalisis dan kemudian menarik kesimpulan berkaitan dengan masalah penelitian. Adapun pendekatan normatif yaitu dengan memberikan tinjauan tentang implementasi, fenomena, dan aktivitas jasa transportasi online Go-Jek dalam perspektif bisnis syariah.

\section{Sumber, Metode Pengumpulan, dan Teknik Analisis Data}

Dalam penelitian ini, sumber data yang digunakan terdiri dari dua jenis sumber data yaitu, data primer dan data sekunder (Amiruddin dan Zainal Asikin, 2004). Metode pengumpulan data adalah teknik yang dipergunakan untuk mengumpulkan jenis-jenis data yang akan diteliti (Suharsimi Arikunto, 2003). Adapun metode pengumpulan data yang digunakan dalam peneltian ini terdiri dari tiga metode yaitu, observasi, wawancara dan dokumentasi. Adapun teknik pengelolahan dan analisis data menggunakan tiga tahap yaitu tahap reduksi data, penyajian data, penarikan kesimpulan.

\section{HASIL DAN PEMBAHASAN}

\section{Pandangan Pengemudi Jasa Transportasi Ojek Pangkalan dengan adanya Jasa Transpotasi Online Go-Jek}

Beralihnya pengguna ojek pangkalan ke ojek online Go-Jek membuat beberapa pekerja ojek pangkalan mengeluh. Beberapa pekerja tersebut menyuarakan keluhan mereka dengan mengadakan demo dimana-mana. Tidak sedikit dari mereka yang melarang ojek online untuk beroperasi di daerah tempat pangkalan mereka berada. Bahkan ada juga oknum-oknum yang menggunakan kekerasan fisik untuk menakut-nakuti pengemudi ojek online agar tidak beroperasi dan mengambil penumpang ojek pangkalan.

Dari beberapa hasil wawancara yang telah dilakukan salah satunya adalah wawancara dengan pengemudi ojek pangkalan yang selalu mangkal di pangkalan ojek Baruga Antang yang mengeluhkan adanya ojek online yaitu Pak Syaripuddin atau sering dipanggil Daeng Uddin yang sudah sekitar 10 tahun menjadi tukang ojek pangkalan Baruga Antang mengatakan bahwa:

"Memang selama ada ojek online pendapatan kami menurun yang biasanya sebelum ada ojek online, pendapatan kami bisa dapat diatas Rp. 100.000/hari, tapi setelah ada ojek online, pendapatan kami hanya kisaran Rp. 50.000 an, bahkan terkadang di bawah Rp. 50.000 , hal itu karena banyak pengemudi ojek online yang mengambil penumpang di wilayah ojek pangkalan." 
Penurunan pendapatan tidak hanya dirasakan di pangkalan ojek antang, akan tetapi juga terjadi di pangkalan ojek tello dan pangkalan ojek aspol tello. Seperti hasil wawancara yang dilakukan dengan salah satu tukang ojek tello yaitu Daeng Pase yang sudah sekitar 15 tahun menjadi tukang ojek pangkalan yang juga mengeluhkan adanya ojek online yang mengatakan bahwa:

"Pendapatan kami berkurang sekali, selama ada ojek online, pendapatannya hanya kisaran Rp. 30.000- 40.000/hari, padahal masih ada 4 orang anak yang harus dibiayai."

Berdasarkan hasil wawancara yang telah dilakukan, bukan hanya mengenai berkurangnya pendapatan saja yang pengemudi ojek pangkalan keluhkan, mereka juga mengeluhkan tentang cara penjemputan yang dilakukan oleh pengemudi ojek online, seperti yang disebutkan oleh Daeng Udding yang mengatakan bahwa:

“Biasa itu de', ada pengemudi ojek online yang mengambil penumpang di dekat pangkalan ini, tidak menggunakan aplikasi, tapi dengan cara di panggil langsung, jadi itu kami tidak setuju dengan cara seperti itu, harusnya tetap pakai aplikasi."

Berdasarkan informasi yang disampaikan oleh Chief Human Resources Officer Go-Jek Indonesia, Monica Oudang di Makassar untuk terus berkomitmen dalam merangkul tukang ojek pangkalan agar bisa bergabung dan menghindari terjadinya potensi konflik saat masuk atau menggarap wilayah baru yang ketika dikonfirmasi mengenai ungkapan tersebut, salah satu tukang ojek pangkalan aspol tello yang bernama Daeng Sapong Slamet yang telah diwawancarai mengatakan bahwa:

“Sebenarnya de', ada ji sosialisasi dan ajakan dari Go-Jek dan teman-teman untuk bergabung menjadi driver ojek online, tapi kami ini yang masih bertahan menjadi tukang ojek pangkalan sudah tua dan rata-rata sudah berumur yang terkendala dengan pengetahuan penggunaan aplikasi Go-Jek atau cara penggunaan aplikasinya, sebenarnya disini dulu banyak tukang ojek yang bergabung menjadi ojek pangkalan, tetapi selama ada perusahaan Go-Jek sebagian kami yang masih muda dan paham menggunakan aplikasi Go-Jek pindah menjadi pengemudi ojek online, tapi syaratnya, mereka yang sudah pindah tidak boleh lagi bergabung disini jadi ojek pangkalan."

Salah satu pertanyaan pada saat wawancara berlangsung adalah ketika ditanya mengenai tentang harapan daripada tukang ojek pangkalan kepada Go-Jek ataupun ojek online dalam hal penjemputan penumpang adalah sesuai dengan hasil wawancara salah satu tukang ojek pangkalan aspol tello yang bernama Daeng Sapong Slamet yang telah diwawancarai mengatakan bahwa:

“Sebenarnya de', memang pertama awal-awalnya ojek online muncul, kami semua disini sepakat menolak ojek online, tapi karena beberapa teman kami disini sudah bergabung dan mereka suka dengan kerjaan driver ojek online, jadi kami setuju-setuju saja, tapi yang kami disini harapkan ada saling pengertian atau kompromi dari pihak ojek online 
khusus untuk pangkalan kompleks perumahan untuk tidak menjemput di dalam kompleks, karena itu ji kasihan yang kami harapkan, tetapi kalau ingin mengantar masuk penumpang atau mengantar makanan boleh, dengan syarat helmnya disimpan di pangkalan dan setelah mengantar makanan, baru boleh diambil."

Berdasarkan dari beberapa hasil wawancara yang telah dilakukan bahwa, dalam pandangan pengemudi ojek pangkalan, kehadiran jasa transportasi ojek online Go-Jek berdampak pada penurunan pendapatan pengemudi ojek pangkalan yang disebabkan oleh beralihnya pengguna jasa angkutan ojek pangkalan ke jasa transportasi ojek online. Para pengemudi ojek pangkalan menganggap bahwa jasa transportasi ojek online Go-Jek telah mengambil hak pengemudi ojek pangkalan dalam mengambil atau menjemput penumpang di wilayah ojek pangkalan, sehingga hal tersebut yang membuat pengemudi ojek pangkalan melakukan penghadangan kepada pengemudi ojek online yang mengambil atau menjemput penumpang di wilayah ojek pangkalan. Para pengemudi ojek pangkalan juga merpersoalkan tentang sebagian pengemudi ojek online yang tidak menggunakan aplikasi onlinenya dalam menjemput penumpang, akan tetapi pengemudi ojek online langsung memanggil calon penumpang di wilayah ojek pangkalan tanpa menggunakan aplikasi online Go-Jek.

Oleh karena itu, para pengemudi ojek pangkalan berharap bahwa, adanya saling pengertian atau kompromi dari pihak perusahaan jasa angkutan ojek online Go-Jek untuk memahami dan memberitahukan kepada para mitra bisnisnya yang dalam hal ini adalah pengemudi ojek online Go-Jek untuk tidak mengambil atau menjemput penumpang di wilayah ojek pangkalan, sehingga penghadangan, konflik atau perselisihan yang sering terjadi dapat diatasi dan tidak ada lagi perselisihan yang terjadi di antara pengemudi ojek pangkalan dan ojek online.

\section{Pandangan Pengguna (Pengemudi Ojek Online dan Penumpang Ojek Online) Pandangan Pengguna sebagai Pengemudi Ojek Online}

Tak dapat dipunkiri dan harus diakui bahwa bisnis angkutan berbasis online ini merupakan terobosan baru di bidang jasa transportasi. Walaupun menuai banyak kontroversi, perkembangan teknologi yang pesat tidak dapat ditahan dan dihindari sehingga setiap teknologi baru dapat teraplikasikan dalam kehidupan sehari-hari, terlepas dari masalah tersebut, masyarakat Indonesia sangat memerlukan sarana jasa angkutan yang nyaman, aman, tepat waktu dan tidak mahal. Kehadiran perusahaan Go-Jek juga membuka lapangan kerja dapat mengurangi tingkat pengangguran. 
Berdasarkan hasil wawancara yang telah dilakukan dengan beberapa pengemudi ojek online Go-Jek, salah satunya adalah pengemudi ojek online Go-Jek yang bernama Rudi R yang berplat motor DD. 3939 yang mengatakan bahwa:

"Dengan adanya ini Go-Jek sangat membantu bagi kamiyang dulunya tidak memiliki pekerjaan dan pendapatan, sekarang ini menjadi pengemudi ojek online Go-Jek sudah menjadi pekerjaan saya, sehigga dengan menjadi pengemudi ojek online Go-Jek, saya bisa membiayai kebutuhan sehari-hari istri dan 2 orang anak saya."

Hasil wawancara dengan Rudi sebelumnya selaku pengemudi ojek online Go-Jek yang juga senada dengan wawancara yang dilakukan dengan pengemudi ojek lainnya yang bernama Kaharuddin yang juga mengatakan bahwa:

"Kehadiran perusahaan Go-Jek juga memberikan peluang pekerjaan kepada saya, bahkan pekerjaan sebagai pengemudi ojek online Go-Jek lumayan menjanjikan dalam hal pendapatan, jika banyak orderan penghasil sehari bisa sampai 150.000-200.00o bahkan bisa lebih dalam perhari, apalagi jika bisa capai target orderan, baru lebih dari itu, saya itu orang wajo, jadi saya datang ke makassar cari kerja sebagai pengemudi ojek online dan alhamdulillah lumayan juga penghasilannya, dari pada tinggal di kampung jadi pengangguran, walaupun terkadang tidak menentu penghasilannya yang tergantung dengan jumlah orderan yang masuk, tapi lumayanlah untuk kebutuhan sehari-hari dan juga bisa disimpan sebagian, saya sudah setahun menjadi driver ojek online dan sampai sekarang saya masih senang menjadi driver ojek online."

Hasil wawancara tersebut menunjukkan bahwa kehadiran ojek online Go-Jek memberikan kesempatan kerja sebagai pengemudi ojek online Go-Jek, sehingga berdampak pada berkurangnya tingkat pengangguran dan meningkatkan kesejahteraan para pengemudi ojek online Go-Jek. Salah satu hasil wawancara dengan pengemudi ojek online Go-Jek mengenai skema pembagian keuntungan dan perjanjian kemitraan antara pihak Go-Jek dengan pengemudi ojek online yang mengatakan bahwa:

"Sepengetahun saya, untuk skema pembagian keuntungan pihak Go-Jek mendapatkan $20 \%$ dan pengemudi ojek online mendapatkan $80 \%$ dari setiap transaksi atau pada saat mendapatkan orderan dan saya fikir pembagian itu masih wajar, karena pihak Go-Jek sebagai penyedia layanan yang menghubungkan antara penumpang dengan pengemudi ojek online adapun mengenai perjanjian dan ketentuan bermitra yang lain sampai saat ini saya fikir tidak ada masalah".

Kehadiran Go-Jek juga memberikan kesempatan kerja bagi masyarakat yang ingin mencari penghasilan tambahan. Masyarakat yang sudah memiliki pekerjaan tetap dan ingin mendapatkan penghasilan tambahan dapat bergabung menjadi pengemudi ojek online, hal tersebut berdasarkan hasil wawancara yang telah dilakukan dengan salah satu pengemudi ojek online yang bernama Jusman yang mengatakan bahwa:

"Pekerjaan tetap saya sebenarnya adalah guru bimbingan di salah satu tempat kursus di makassar, tapi disela-sela jadwal mengajarku, saya gunakan untuk mencari penghasilan tambahan sebagai pengemudi ojek online Go-Jek, hanya sebagai pekerjaan tambahan atau sampingan saja, karena kalau di tempat kursus, masuk kerjanya darijam 09:00-17:00, sebelum ke tempat kursus, saya mencari penumpang 
ojek online terlebih dahulu, biasa juga setelah dari tempat kursus, kan lumayan untuk tambahan penghasilan untuk digunakan membeli bensin, makan dan kebutuhan lainnya."

Oleh karena itu, dalam pandangan pengemudi ojek online, kehadiran perusahaan jasa angkutan online Go-Jek berdampak positif bagi masyarakat dalam hal penyediaan lapangan kerja. Kehadiran perusahaan Go-Jek membuka peluang dan kesempatan kerja bagi masyarakat yang tidak memiliki pekerjaan, sehingga kehadiran perusahaan Go-Jek dianggap membantu masyarakat dalam meningkatkan kesejahteraan hidup para pengemudi ojek online Go-Jek.

\section{Pandangan Pengguna sebagai Penumpang Ojek Online Go-Jek}

Berdasarkan hasil wawancara yang telah dilakukan yang salah satunya hasil wawancara dengan seorang guru sekolah dasar di salah sekolah swasta di Makassar yang bernama Ibtisam yang mengatakan bahwa:

"Saya sudah sekitar 2 tahun menggunakan jasa angkutan ojek online Go-Jek dan memang sangat membantu, dikarenakan cara pesannya mudah, dimanapun bisa, apalagi saya tinggal di dalam kompleks perumahan, pesan ojek hanya lewat handphone melalui aplikasi Go-Jek, tidak seperti ojek pangkalan atau bentor haruski lagi keluar cari di luar atau ke pangkalan kalau mau minta diantar, tidak hanya itu, tarifnya juga lebih murah dan terkadang ada promo-promo diskon tarifnya, cara pembayarannya juga bisa tunai dan non tunai, hanya dengan Go-Pay, sehingga lebih efisien, hemat waktu dan tenaga, mudah dan praktis, aman dan terpercaya, tarif, rute dan jarak perjalanan serta identitas pengemudinya jelas yang bisa dilihat dalam aplikasinya, jumlah pengemudi yang banyak dan memiliki berbagai jenis layanan, pokoknya lebih baguslah dibandingkan dengan ojek pangkalan atau bentor.”

Senada dengan wawancara sebelumnya, salah satu konsumen ojek online Go-Jek yang bernama Rahmat juga mengatakan bahwa:

"Ojek online khususnya Go-Jek, sangat membantu dalam mendukung aktivitas, memberikan berbagai macam jenis layanan, jadi bukan hanya sebagai ojek saja, tapi bisa juga digunakan untuk memesan makanan ataupun pengiriman barang dan masih banyak jenis layanan lain yang juga sangat membantu, menurutku, kata beliau, Go-Jek telah berhasil mengubah image atau pandangan ojek yang dulunya hanya memberikan layanan antar atau jemput penumpang atau pelayanan yang diberikan yang dulunya asal-asalan dan tidak mengutamakan layanan atau service dan kepuasan konsumen, dengan adanya Go-Jek atau ojek online, semua pandanganpandangan tentang Go-Jek yang jauh lebih baik."

Meskipun Go-Jek memberikan banyak sekali kemudahan dalam memberikan layanan, seperti, praktis, tarif murah dan transparan, aman dan terpercaya, memiliki kemudahan dalam hal membayar tunai atau non tunai, memberikan informasi tentang pengemudi dan kendaraaannya, dapat mengukur waktu penjemputan dan tujuan dan juga ada catatan histori perjalanan, akan tetapi masih ada beberapa kekurangan yang masih harus diperbaiki dan 
dipertimbangkan, seperti yang diungkapkan oleh salah satu informan yang telah diwawancarai yang mengatakan bahwa:

"Secara keseluruhan layanan yang diberikan oleh Go-Jek sudah lebih baik jika dibandingkan dengan layanan jasa angkutan ojek pangkalan atau bentor, akan tetapi ada ada hal yang mungkin dapat menjadi pertimbangan untuk perusahaan Go-Jek dan juga pengemudi ojek online untuk tetap meningkan kualitas layanan kepada konsumen seperti, saat ini belum ada ketersediaannya menu preference atau menu dalam aplikasi Go-Jek untuk memilih sendiri pengemudi ojek online yang diinginkan, seperti konsumen wanita/perempuan yang terkadang menginginkan pengemudi ojek online wanita dan juga untuk motor yang digunakan sebaiknya tetap diperhatikan kelayakan motor yang digunakan, karena hal tersebut juga akan mempengaruhi kualitas layanan yang diberikan."

Berdasarkan hasil wawancara yang telah dilakukan, maka dapat disimpulkan bahwa, dalam pandangan pengguna sebagai konsumen atau penumpang jasa transportasi online GoJek, kehadiran ojek online Go-Jek saat ini memberikan banyak manfaat dan kemudahan, seperti lebih efisien, hemat waktu dan tenaga, mudah dan praktis, aman dan terpercaya, tarif murah, banyak diskon dan promo, bisa dibayar tunai dan non tunai, jumlah pengemudi yang banyak dan memiliki berbagai jenis layanan. Hal tersebut juga senada dengan hasil penelitian yang dilakukan oleh salah satu Lembaga penelitian yaitu Lembaga Demografi Fakultas Ekonomi dan Bisnis Universitas Indonesia yang dalam hasil penelitiannya menyebutkan bahwa, 99\% konsumen merasa puas menggunakan Go-Jek, 98\% konsumen merasa nyaman menggunakan Go-Jek dan 96\% konsumen merasa aman dalam menggunakan layanan Go-Jek

Meskipun demikian, jasa transportasi online Go-Jek belum 100\% memberikan kepuasan atau pelayanan kepada konsumen, ada beberapa hal yang menjadi keluhan konsumen ketika ingin menggunakan jasa transportasi ojek online, seperti tidak ada menu preference atau menu dalam aplikasi Go-Jek untuk memilih pengemudi ojek online yang diinginkan dan untuk motor yang digunakan sebaiknya tetap diperhatikan kelayakan motornya, karena hal tersebut dapat mempengaruhi kualitas layanan yang diberikan. Oleh karena itu, diharapkan bagi perusahaan jasa angkutan online Go-Jek untuk tetap meningkatkan kualitas layanan kepada konsumen, sehingga konsumen tetap bertahan untuk menggunakan jasa transportasi online Go-Jek.

\section{Perspektif Bisnis Syariah pada Jasa Transportasi Online Go-Jek}

Dalam perspektif bisnis syariah, bisnis dapat dikatakan sebagai bisnis yang sesuai dengan perspektif bisnis syariah jika telah memenuhi atau menjalankan 3 (tiga) syarat dalam konsep bisnis syariah antara lain, prinsip dasar bisnis syariah, etika bisnis syariah dan tujuan bisnis syariah. 


\section{Prinsip Dasar Bisnis Syariah}

Dalam perspektif bisnis syariah, prinsip dasar bisnis syariah menjadi hal yang utama dalam menentukan bisnis tersebut sesuai dengan bisnis syariah atau tidak. Prinsip dasar bisnis syariah tersebut adalah halal dan tayyib (baik) yang dalam hal ini tayyib (baik) terdiri dari ihsan dan tawazun.

1. Prinsip dasar halal

Prinsip dasar halal dalam bisnis yang dilakukan yaitu dengan menghindari kegiatan atau transaksi bisnis yang dilarang yang dalam al-Qur'an kegiatan atau transaksi bisnis yang dilarang tersebut adalah kegiatan atau transaksi bisnis yang mengandung unsur riba, maysir, gharar, al-batil (kebatilan), al-fasad (kerusakan) dan al-zalim (kezaliman). Berdasarkan kaidah fikih yang disepakati oleh banyak ulama yang menyebutkan bahwa, segala hal dalam berbisnis atau bermuamalah pada dasarnya adalah dibolehkan kecuali ada dalil yang mengharamkannya (al-ashlu fi al-mu'amalah al-ibaahah illaa an-yadulla daliilaan 'alaa tahrïmihaa).

Pada dasarnya kegiatan atau transaksi dalam bisnis jasa transportasi online Go-Jek adalah kegiatan atau transaksi dalam hal jual beli jasa, perusahaan jasa transportasi online Go-Jek menawarkan sebuah layanan jasa transportasi ojek yang berbasis online atau dengan menggunakan aplikasi online Go-Jek, sehingga dalam proses transaksi calon konsumen atau penumpang yang ingin menggunakan jasa angkutan ojek online harus memesannya melalu aplikasi online Go-Jek. Oleh karena itu, dalam hal jual beli barang atau jasa, rukun dan syarat jual beli menjadi bagian yang harus dipenuhi terlebih dahulu untuk mengetahui kegiatan atau transaksi yang dilakukan sesuai dengan prinsip dasar bisnis syariah. Adapun rukun dalam sebuah transaksi jual beli yaitu adanya akad (ijab kabul), orang yang berakad atau pihak-pihak yang berakad, ma'kud 'alaih atau barang dan jasa yang diperjual belikan dan ada nilai tukar barang pengganti yang dalam hal ini adalah alat pembayarannya (uang). Adapun syarat yang dimaksud dalam hal ini adalah sesuatu yang disandarkan dalam rukun jual beli, seperti dalam hal akad (ijab kabul), harus jelas akad dalam transaksinya, pihak-pihak yang melakukan transaksi harus berakal atau memahami transaksi yang akan dilakukan, barang dan jasa yang diperjual belikan merupakan barang dan jasa yang halal, baik dan jelas sumbernya baik kualitas, berat, takaran dan ukuran yang jelas sehingga tidak menimbulkan keraguan, ada nilai tukar pengganti barang dan jasa yaitu sesuatu yang memenuhi tiga syarat seperti dapat menyimpan nilai (store of value), dapat menilai atau menghargakan suatu barang (unit of account) dan dapat dijadikan alat tukar (medium of exchange).

Oleh karena itu, jika dikaitkan dengan jasa transportasi online Go-Jek berdasarkan transaksi bisnis yang dilakukan dalam proses jual beli jasa telah memenuhi rukun dan syarat 
dalam jual beli barang dan jasa sebagai kegiatan atau transaksi bisnis yang halal, karena dalam proses transaksi jual beli jasa angkutannya atau sebelum menggunkan jasa angkutannya, konsumen atau calon penumpang terlebih dahulu memesan melalui aplikasi online Go-Jek yang dalam aplikasi online Go-Jek dengan jelas ditampilkan jenis layanan yang diinginkan, harga atau biaya jasa angkutan, rute perjalanan, pengemudi ojek online yang menjemput atau mengantar dan juga tersedia layanan komunikasi atau pengiriman pesan (chat/sms) yang dapat digunakan antara pengemudi ojek online dengan calon penumpang, sehingga sebelum calon konsumen atau penumpang melakukan akad transaksinya atau memutuskan untuk menggunakan atau memesan jasa angkutan online Go-Jek dapat terlebih dahulu mempertimbangkan hal-hal tersebut.

Oleh karena itu, berdasarkan penjelasan tersebut, maka dapat disimpulkan bahwa dalam transaksi jual beli jasa transportasi ojek online dibolehkan dalam Islam selama kegiatan atau transaksi bisnis yang dilakukan tidak mengandung unsur riba, maysir, gharar, al-batil (kebatilan), al-fasad (kerusakan) dan al-zalim (kezaliman).

2. Prinsip dasar tayyib (baik)

Tayyib (baik) dalam hal ini memeliki pengertian yang mencakup segala nilai-nilai kebaikan yang menjadi nilai tambah dari hal-hal yang halal dalam rangka pencapaian tujuan bisnis syariah yaitu memperoleh keuntungan material dan non material, mendorong terjadinya pertumbuhan ekonomi, menjaga keberlangsungan bisnis dan memperoleh berkah dan rida Allah yang dalam hal ini tayyib (baik) terdiri dari ihsan dan tawazun.

a. Ihsan

Ihsan adalah memberikan perlakuan yang terbaik atau dalam kegiatan bisnis perlakuan yang terbaik dalam hal ini adalah memberikan pelayanan yang terbaik kepada konsumen dan menghindari perilaku yang merusak dan merugikan. Sehingga jika dikaitkan dengan jasa angkutan online Go-Jek dalam hal memberikan pelayanan kepada konsumen atau masyarakat dinilai telah memenuhi prinsip dasar tayyib (baik) dalam hal ihsan. Hal tersebut berdasarkan hasil wawancara dengan pengguna layanan sebagai konsumen atau penumpang jasa transportasi online Go-Jek yang mengatakan bahwa kehadiran ojek online Go-Jek saat ini memberikan banyak manfaat dan kemudahan, seperti lebih efisien, hemat waktu dan tenaga, mudah dan praktis, aman dan terpercaya, tarif murah, banyak diskon dan promo, bisa dibayar tunai dan non tunai, jumlah pengemudi yang banyak dan memiliki berbagai jenis layanan. Hal tersebut juga didukung oleh salah satu lembaga penelitian yang menyebutkan bahwa dalam hal memberikan pelayanan kepada konsumen jasa angkutan online Go-Jek, 99\% merasa puas menggunakan Go-Jek, 98\% konsumen merasa nyaman menggunakan Go-Jek dan 96\% konsumen merasa aman dalam menggunakan layanan Go- 
Jek, sehingga dapat disimpulkan bahwa perusahaan Go-Jek telah menjalankan prinsip dasar tayyib (baik) dalam hal ihsan atau memberikan pelayanan dengan baik kepada konsumennya.

\section{b. Tawazun}

Tawazun diartikan sebagai neraca keseimbangan dalam arti makro yang mencakup diantaranya keseimbangan antara spritual dan material, eksplorasi dan konservasi, sektor finansial dan sektor riil, resiko dan hasil atau suatu perlakuan yang seimbang atau adil dalam menjalankan kegiatan bisnis yang harus memperhatikan hak-hak mitra bisnisnya sesuai dengan perjanjian dan kesepakatan sebagai mitra bisnisnya, sehingga jika konsep tawazun ini dikaitkan dengan bisnis jasa transportasi online Go-Jek, maka perusahaan jasa transportasi online Go-Jek dinilai telah menjalankan konsep tawazun, hal tersebut berdasarkan hasil wawancara dengan pengemudi ojek online yang mengatakan bahwa, untuk skema pembagian keuntungan pihak Go-Jek mendapatkan 20\% dan pengemudi ojek online mendapatkan $80 \%$ dari setiap transaksi atau pada saat mendapatkan orderan dan menurut pengemudi ojek online tersebut, pembagian keuntungan tersebut masih wajar, karena pihak Go-Jek yang berperan sebagai penyedia layanan yang menghubungkan antara penumpang dengan pengemudi ojek online, adapun mengenai perjanjian dan ketentuan bermitra yang lain sampai saat ini tidak ada masalah.

Salah satu hasil penelitian juga menyebutkan bahwa mitra bisnis menilai positif kerjasama atau kemitraan bersama Go-Jek dalam hal ini mayoritas mitra Go-Ride melihat positif kemitraan dengan Go-Jek dengan indikator peraturan hubungan perjanjian kemitraan dengan Go-Jek (86\%) dan kesempatan bernegosiasi atau berdialog dengan manajemen GoJek (83\%), sehingga dapat disimpulkan bahwa perusahaan Go-Jek telah menjalankan prinsip dasar tayyib (baik) dalam hal tawazun yaitu memberikan perlakuan yang seimbang atau adil dalam menjalankan kegiatan bisnisnya dan telah memperhatikan hak-hak mitra bisnisnya.

\section{Etika Bisnis Syariah}

Penerapan etika bisnis syariah secara berkesinambungan dapat menciptakan suasana yang kondusif dalam pembentukan budaya bisnis yang islami (islamic corporate culture). Oleh karena itu, setiap pelaku bisnis syariah harus memiliki rumusan yang jelas tentang etika bisnis syariah bagi kegiatan bisnisnya, hal tersebut dapat mendukung pelaksanaan bisnis dengan landasan dan cara yang baik serta sikap saling rida. Implementasi etika bisnis syariah dalam kegiatan bisnis tersebut akan tercapai jika telah memenuhi prinsip-prinsip etika bisnis syariah seperti, customer oriented (kepuasan konsumen), transparansi, persaingan yang sehat, dan fairness (keadilan). 


\section{Customer oriented (kepuasan konsumen)}

Dalam bisnis, prinsip customer oriented atau kepuasan konsumen yang menjadi bagian penting yang selalu harus diperhatikan. Untuk melakukan prinsip tersebut diperlukan nilai-nilai kejujuran, keadilan, serta amanah dalam melaksanakan perjanjian dalam transaksi bisnis atau dalam memberikan pelayanan kepada konsumen. Sehingga jika terjadi perbedaan pandangan atau kesalahpahaman, maka dapat diselesaikan dengan baik, damai dan adil tanpa ada unsur penipuan atau unsur lain yang dapat merugikan salah satu pihak, hal tersebut dilakukan untuk memaksimalkan pelayanan terbaik kepada konsumen. Selain itu prinsip customer oriented juga memberikan kebolehan kepada konsumen atas hak khiyar (meneruskan atau membatalkan transaksi) jika ada indikasi penipuan atau merasa dirugikan.

Oleh karena itu, jika hal tersebut dikaitkan dengan bisnis jasa transportasi online GoJek, maka perusahaan jasa transportasi online Go-Jek dinilai telah menerapkan prinsip customer oriented tersebut dengan baik, hal tersebut berdasarkan hasil wawancara yang telah dilakukan yang mengatakan bahwa kehadiran ojek online Go-Jek memberikan banyak manfaat dan kemudahan, seperti lebih efisien, hemat waktu dan tenaga, mudah dan praktis, aman dan terpercaya, tarif murah, banyak diskon dan promo, bisa dibayar tunai dan non tunai, jumlah pengemudi yang banyak dan memiliki berbagai jenis layanan. Hal tersebut juga didukung oleh salah satu lembaga penelitian yang menyebutkan bahwa dalam hal memberikan pelayanan kepada konsumen jasa angkutan online Go-Jek, 99\% merasa puas menggunakan Go-Jek, 98\% konsumen merasa nyaman menggunakan Go-Jek dan 96\% konsumen merasa aman dalam menggunakan layanan Go-Jek, sehingga dapat disimpulkan bahwa dalam hal memberikan pelayanan kepada konsumen, perusahaan Go-Jek telah menjalankan prinsip customer oriented atau kepuasan konsumen dengan baik.

2. Transparansi (keterbukaan/kejujuran)

Prinsip kejujuran dan keterbukaan dalam bisnis merupakan kunci keberhasilan dan kejujuran tetap menjadi prinsip utama sampai saat ini. Bentuk transparansi terhadap mitra bisnis dan konsumen adalah ketika perusahaan terbuka mengenai harga atau biaya, kualitas dan mutu layanan, skema pembagian keuntungan kepada mitra bisnis dan lain-lain yang bertujuan untuk memberikan informasi kepada mitra bisnis ataupun kepada konsumen ketika ingin bergabung dengan perusahaan Go-Jek sebagai mitra bisnis atau sebagai konsumen pengguna jasa angkutan online Go-Jek.

Oleh karena itu, berdasarkan hasil wawancara yang telah dilakukan dengan konsumen yang mengatakan bahwa bentuk transparansi jasa transportasi online Go-Jek kepada konsumennya adalah berkaitan dengan harga atau biaya jasa, identitas pengemudi ojek online, jarak dan rute perjalanan serta jenis layanan lainnya yang dinilai telah memberikan 
informasi yang jelas kepada konsumen yang ditampilkan dalam aplikasi online Go-Jek, sehingga sebelum memutuskan untuk menggunakan jasa transportasi online Go-Jek, konsumen dapat mengetahui secara jelas mengenai harga atau biaya jasa, identitas pengemudi ojek online, jarak dan rute perjalanan serta jenis layanan lainnya, sedangkan bentuk transparansi jasa transportasi online Go-Jek kepada pengemudi ojek online Go-Jek adalah mengenai skema pembagian keuntungan yang dalam hal ini, perusahaan Go-Jek sebagai penyedia layanan mendapatkan 20\% dari setiap transaksi atau orderan yang masuk pada mitra bisnis dan 80\% untuk mitra bisnisnya, sehingga dapat disimpulkan bahwa perusahaan jasa angkutan online Go-Jek dinilai telah menerapkan dan menjalankan prinsip transparansi atau keterbukaan tersebut kepada mitra bisnis dan konsumennya.

3. Persaingan yang sehat

Persaingan yang tidak sehat atau secara bebas dalam arti menghalalkan segala cara dalam setiap kegiatan bisnis dengan melanggar hak-hak pesaing bisnisnya yang bertentangan dengan prinsip etika bisnis syariah. Strategi dalam persaingan bisnis dalam etika bisnis syariah dibolehkan dengan kriteria bersaing secara baik atau menganjurkan para pebisnis untuk besaing secara positif (fastabiqul khairat) dengan memberikan konstribusi yang baik dari bisnisnya bukan untuk menjatuhkan atau merugikan pebisnis lainnya. Adapun yang menjadi pesaing bisnis jasa angkutan online Go-Jek dalam hal ini adalah jasa angkutan online Grab, Uber, Golek, Anterin, Bajaj App, Transjek, Wheel Line, Ojek Syar’i, Blue Jek dan jasa angkutan Ojek Pangkalan. Berdasarkan fakta yang terjadi di lapangan, salah satu pihak yang merasa dirugikan sejak kehadiran jasa transportasi online Go-Jek adalah jasa transportasi ojek pangkalan.

Berdasarkan dari hasil wawancara yang telah dilakukan bahwa, dalam pandangan pengemudi ojek pangkalan, kehadiran jasa angkutan ojek online Go-Jek dianggap telah mengambil hak pengemudi ojek pangkalan dalam mengambil atau menjemput penumpang di wilayah ojek pangkalan, sehingga hal tersebut yang membuat pengemudi ojek pangkalan melakukan penghadangan kepada pengemudi ojek online yang mengambil atau menjemput penumpang di wilayah ojek pangkalan. Oleh karena itu, salah satu bentuk kebijakan dalam menjaga prinsip etika bisnis dalam persaingan bisnis yang sehat yang dilakukan perusahaan jasa angkutan online Go-Jek dalam menyikapi persoalan perselisihan atau konflik tersebut adalah dengan membekali pengemudi ojek online Go-Jek dengan pengetahuan untuk berhatihati atau tidak mengambil atau menjemput penumpang dalam zona wilayah rawan konflik seperti yang dirilis dalam salah satu berita media online kompasiana yang menyebutkan bahwa pihak manajemen Go-Jek telah membekali pengemudi ojek online Go-Jek tentang zona atau wilayah yang rawan dan sering terjadi konflik dengan ojek pangkalan. Manajemen 
Go-Jek juga memperingatkan kepada para pengemudi ojek online untuk tetap berhati-hati dalam mengantar atau mengambil penumpang di wilayah tersebut, serta kebijakan Go-Jek untuk tetap berkomitmen merangkul ojek pangkalan, hal tersebut disampaikan melalui salah satu media berita online Antaranews.com online merilis berita tentang "Go-Jek Indonesia Rangkul Tukang Ojek Hindari Konflik", yang menyebutkan bahwa Go-jek Indonesia terus berkomitmen dalam merangkul tukang ojek pangkalan agar bisa bergabung dan menghindari terjadinya potensi konflik saat masuk atau menggarap wilayah baru, sehingga penghadangan, konflik atau perselisihan yang sering terjadi dapat diatasi dan tidak ada lagi perselisihan yang terjadi di antara pengemudi ojek pangkalan dan ojek online.

Berdasarkan penjelasan tersebut, maka dapat disimpulkan bahwa perusahaan jasa transportasi online Go-Jek dinilai telah menjalankan atau menerapkan prinsip etika bisnis syariah dalam hal persaingan yang sehat yang dibuktikan dengan adanya kebijakan-kebijakan dari perusahaan jasa transportasi online Go-Jek yang berusaha untuk tetap menjaga eksistensi atau keberlangsungan bisnis pesaingnya yang dalam hal ini adalah jasa transportasi ojek pangkalan.

4. Fairness (keadilan)

Salah satu bentuk keadilan dalam prinsip etika bisnis syariah adalah saling menjaga hak-hak dalam menjalankan bisnis, baik hak kepada konsumen, mitra bisnis (pengemudi ojek online) dan pesaing bisnisnya, sehingga tidak ada pihak yang merasa dirugikan atas bisnis yang sedang dijalankan. Bentuk keadilan kepada konsumen yaitu dengan memberikan hakhak konsumen dalam menggunakan jasa transportasi online Go-Jek, baik itu berupa kejelasan informasi serta keamanan dalam menggunakan jasa angkutan online Go-Jek dan tidak melakukan penipuan yang dapat menyebabkan kerugian bagi konsumen yang dalam hasil wawancara dalam pandangan konsumen atau penumpang ojek online mengatakan bahwa dengan menggunakan jasa transportasi ojek online, maka dapat lebih efisien, hemat waktu dan tenaga, mudah, praktis, aman, tarif, rute dan jarak perjalanan serta identitas pengemudi ojek online yang dapat dilihat dengan jelas dalam aplikasi ojek online Go-Jek.

Adapun bentuk keadilan kepada mitra bisnis yang dalam hal ini adalah pengemudi ojek online yaitu dengan memperhatikan skema pembagian keuntungan yang didasari atas saling rida yang berdasarkan hasil wawancara dengan pengemudi ojek online yang mengatakan bahwa, untuk skema pembagian keuntungan pihak Go-Jek mendapatkan 20\% dan pengemudi ojek online mendapatkan 80\% dari setiap transaksi atau pada saat mendapatkan orderan dan menurut pengemudi ojek online, pembagian keuntungan tersebut masih wajar, karena pihak Go-Jek yang berperan sebagai penyedia layanan yang menghubungkan antara penumpang dengan pengemudi ojek online, sedangkan bentuk 
keadilan kepada pesaing bisnis adalah dengan tidak mengambil hak-hak atas konsumen atau penumpang yang ada di wilayah ojek pangkalan. Berdasarkan hasil wawancara dengan pengemudi ojek pangkalan yang mengharapkan adanya saling pengertian atau kompromi dari pihak perusahaan jasa angkutan ojek online Go-Jek untuk memahami dan memberitahukan kepada para mitra bisnisnya yang dalam hal ini adalah pengemudi ojek online Go-Jek untuk tidak mengambil atau menjemput penumpang di wilayah ojek pangkalan, sehingga salah satu bentuk keadilan yang dilakukan oleh perusahaan jasa angkutan online Go-Jek adalah dengan membuat kebijakan seperti membekali pengemudi ojek online Go-Jek dengan pengetahuan untuk berhati-hati atau tidak mengambil atau menjemput penumpang dalam zona wilayah rawan konflik, sehingga dapat menjaga keberlangsungan bisnis pesaingnya untuk tetap eksis dan bertahan dalam memberikan pelayanan jasa angkutan kepada konsumennya.

Oleh karena itu, berdasarkan beberapa penjelasan tersebut, maka jasa angkutan online Go-Jek dalam hal ini dinilai telah menerapkan prinsip keadilan dalam menjalankan bisnisnya yang tetap memperhatikan hak-hak konsumen, mitra bisnis dan pesainnya dalam menjalankan bisnisnya.

\section{Tujuan Bisnis Syariah}

Dalam berbagai kegiatan ekonomi atau bisnis yang dilakukan oleh sesesorang atau perusahaan sudah pasti dengan tujuan tertentu, demikian pula dengan kegiatan ekonomi yang berbasis bisnis syariah yang juga mempunyai tujuan yang akan dicapai yaitu antara lain, memperoleh keuntungan material dan non material, mendorong terjadinya pertumbuhan ekonomi, menjaga keberlangsungan bisnis, memperoleh berkah dan rida Allah.

1. Memperoleh keuntungan material dan non material

Dalam menjalankan bisnis sudah pasti seseorang atau perusahaan menginginkan keuntungan. Namun demikian, keuntungan tersebut tidak sebatas pada keuntungan material semata, akan tetapi juga pada keuntungan non material. Adapun yang menjadi keuntungan non material adalah menciptakan suasana yang kondusif, keamanan, nilai persaudaraan, kesejahteraan dan kepedulian sosial dan sebagainya. Keuntungan material yang tidak disertai dengan keuntungan non material akan melahirkan disharmonisasi dalam kehidupan bermasyarakat.

Sehingga jika dikaitkan dengan jasa transportasi online Go-Jek dalam hal pencapaian tujuan bisnis syariah yaitu memperoleh keuntungan material dan non material dinilai telah berhasil dalam menjalankan bisnisnya, hal tersebut berdasarkan salah satu hasil penelitian yang menyebutkan bahwa dalam hal pencapaian keuntungan material perusahaan jasa transportasi online Go-Jek dinilai memperoleh keuntungan material yang cukup besar, hal 
tersebut berdasarkan konstribusi yang diberikan kepada perekonomian Indonesia sebesar Rp. 44,2 triliun per tahun, sedangkan dalam hal pencapaian keuntungan non material perusahaan jasa transportasi online Go-Jek dinilai telah berhasil dalam hal meningkatkan kepedulian kesejahteran hidup mitra bisnisnya yaitu para pengemudi ojek online dan salah satu bentuk kepedulian perusahaan Go-Jek kepada mitra bisninya adalah program KPR yang bekerjasama dengan bank tabungan negara (BTN) seperti yang dirilis oleh satu satu berita media online yaitu transOnline yang menyebutkan bahwa Go-Jek sebagai perusahaan yang menaungi dan memediasi bisnis ojek online menjadi promotor dalam membuka akses bagi pengemudi ojek online untuk mendapatkan KPR melalui bank tabungan negara (BTN). Kerjasama mulia tersebut untuk membantu memenuhi kebutuhan perumahan bagi para pengemudi ojek online.

Oleh karena itu, maka dapat disimpulkan bahwa dalam hal pencapaian tujuan bisnis syariah yaitu memperoleh keuntungan material dan non material perusahaan jasa transportasi online Go-Jek dinilai telah berhasil dalam menjalankan bisnisnya yang dibuktikan melalui konstribusinya dalam meningkatkan perekonomian Indonesia dan bentuk kepedulian Go-Jek kepada pengemudi ojek online dalam meningkatkan kesejahteraan hidupnya.

2. Mendorong terjadinya pertumbuhan ekonomi

Keuntungan material dan non material yang diperoleh dalam menjalankan bisnis diharapkan dapat mendorong terjadinya pertumbuhan ekonomi. Salah satu hal yang dapat menjadi tolak ukur yang dapat mendorong terjadinya pertumbuhan ekonomi adalah meningkatnya pendapatan masyarakat, sehingga dengan adanya pertumbuhan ekonomi, maka dapat berdampak pada peningkatan kesejahteraan masyarakat. Oleh karena itu, jika dikaitkan dengan pencapaian perusahaan jasa transportasi online Go-Jek dalam hal mendorong pertumbuhan ekonomi dinilai telah berhasil dalam menjalankannya, hal tersebut berdasarkan hasil wawancara yang telah dilakukan yang menyebutkan bahwa kehadiran perusahaan Go-Jek dianggap membantu masyarakat dalam meningkatkan pendapatan yang kemudian dapat meningkatkan kesejahteraan hidup para pengemudi ojek online Go-Jek. Hal tersebut juga didukung oleh salah satu penelitian yang dilakukan oleh Lembaga Demografi Fakultas Ekonomi dan Bisnis Universitas Indonesia Indonesia yang menyebutkan bahwa GoJek memberikan kontribusi positif pada perekonomian nasional. Mitra Go-Jek berkontribusi Rp 44,2 triliun per tahun ke dalam perekonomian Indonesia.

Oleh karena itu, berdasarkan penjelasan tersebut, maka dapat disimpulkan bahwa dalam hal pencapaian tujuan bisnis syariah dalam mendorong terjadinya pertumbuhan ekonomi, perusahaan jasa transportasi online Go-Jek dinilai telah berhasil dalam 
menjalankan bisnisnya yang dibuktikan dengan terjadinya peningkatan perekonomian nasional yang terdiri dari peningkatan pendapatan sebagai mitra bisnis dan berdampak positif pada peningkatan kesejahteraan hidup masyarakat.

3. Menjaga keberlangsungan bisnis

Keberlangsungan bisnis menjadi harapan bagi setiap pelaku bisnis. Keberlangsungan tersebut akan menjadi hal yang tidak mungkin dicapai jika keuntungan dalam berbisnis tidak dapat diperoleh. Atas dasar ini, dalam tujuan bisnis syariah memberikan hak untuk mengambil keuntungan material dan non material sebagai modal atau landasan yang dapat menjaga eksistensi atau keberlangsungan bisnis tersebut.

Pada awalnya berdirinya perusahaan jasa transportasi ojek online Go-Jek hanya menyediakan layanan ojek online Go-Jek yang masih mengandalkan call center untuk menghubungkan penumpang dengan pengemudi ojek online. Seiring dengan perkembangan teknologi dan tuntutan dalam memberikan layanan yang terbaik kepada konsumennya, akhirnya perusahaan jasa transportasi online Go-Jek meluncurkan aplikasi berbasis android dan IOS untuk menggantikan sistem pemesanan menggunakan call center dan membuat berbagai jenis layanan lain seperti Go-Send, Go-Massage, Go-Pay dan layanan lainnya. Perusahaan Go-Jek juga bekerja sama dengan UMKM dalam hal layanan Go-Food. Hal tersebut dilakukan untuk memberikan pelayan yang terbaik kepada konsumennya, sehingga dengan upaya tersebut dapat menjaga eksistensi atau keberlangsungan perusahaan jasa angkutan online Go-Jek. Salah satu pencapaian Go-Jek saai ini yaitu Go-Jek menjadi perusahaan yang menyandang status sebagai perusahaan decacorn atau memiliki valuasi di atas US\$ 10 miliar, seperti yang dirilis lewat berita online liputan6 yang menyebutkan bahwa aplikator angkutan online Go-Jek menembus sejarah baru. Go-Jek, kini menyandang status sebagai decacorn atau startup yang memiliki valuasi di atas US\$ 10 miliar atau setara dengan 140 triliun. Sebelumnya, Go-Jek menggenggam status sebagai unicorn atau startup dengan valuasi di atas US\$ 1 miliar.

Oleh karena itu, berdasarkan penjelasan perkembangan perusahaan Go-Jek tersebut, maka dapat disimpulkan bahwa dalam hal pencapaian tujuan bisnis syariah dalam menjaga keberlangsungan bisnis, perusahaan jasa transportasi online Go-Jek dinilai telah berhasil dalam menjalankan bisnisnya yang dibuktikan dengan berbagai layanan yang diberikan dan pencapaian yang telah diperolehnya sebagai perusahaan yang tetap eksis dan bertahan dalam menjaga keberlangsungan bisnisnya.

4. Memperoleh berkah dan rida Allah.

Dalam perspektif bisnis syariah, pada hakikatnya pencapaian tujuan bisnis syariah dari setiap bisnis yang dilakukan adalah untuk mencapai tujuan yang sangat esensial yaitu 
keberkahan. Maka setiap muslim dalam menjalankan bisnisnya seharusnya mempunyai keyakinan bahwa jika bisnisnya ingin tetap terjaga dalam keberlangsungan bisnisnya dan hidupnya ingin tenang, tenteram, harmonis dan selamat dunia dan akhirat, maka keberkahan menjadi syarat untuk mendapatkan rida Allah swt, sehingga jika dikaitkan dengan bisnis jasa transportasi online Go-Jek, maka bisnis tersebut dapat mencapai tujuan bisnis syariah dalam memperoleh berkah dan rida Allah jika telah menjalankan bisnisnya dengan baik dan memenuhi syaratnya antara lain, prinsip dasar bisnis syariah, etika bisnis syariah dan tujuan bisnis syariah.

Oleh karena itu, berdasarkan dari beberapa penjelasan tersebut, maka dapat disimpulkan bahwa dalam perspektif bisnis syariah pada jasa transportasi online Go-Jek, perusahaan jasa transportasi online Go-Jek dinilai telah memenuhi dan menjalankan konsep bisnis syariah yang terdiri dari prinsip dasar bisnis syariah, etika bisnis syariah dan tujuan bisnis syariah, hal tersebut dilihat berdasarkan penjelasan sebelumnya mengenai prinsip dasar bisnis syariah, etika bisnis syariah dan tujuan bisnis syariah yang dalam disimpulkan bahwa jasa angkutan online Go-Jek dalam hal prinsip dasar bisnis syariahnya dibolehkan dalam Islam selama kegiatan atau transaksi bisnis yang dilakukan tidak mengandung unsur riba, maysir, gharar, al-batil (kebatilan), al-fasad (kerusakan) dan al-zalim (kezaliman). Adapun dalam etika bisnis syariahnya disimpulkan bahwa jasa angkutan online Go-Jek telah menjalankan prinsip-prinsip seperti customer oriented (kepuasan konsumen), transparansi, persaingan yang sehat, dan fairness (keadilan) dengan baik, sedangkan dalam hal tujuan bisnis syariah, jasa angkutan online Go-Jek dinilai telah menjalankan tujuan bisnis syariah seperti memperoleh keuntungan material dan non material, mendorong terjadinya pertumbuhan ekonomi dan menjaga keberlangsungan bisnis, sehingga berdasarkan penjelasan tersebut, maka bisnis jasa angkutan online Go-Jek tersebut dapat dikatakan sebagai bisnis yang memperoleh keberkahan dan rida Allah.

\section{KESIMPULAN}

Dalam pandangan pengemudi ojek pangkalan, kehadiran jasa transportasi ojek online Go-Jek berdampak pada penurunan pendapatan pengemudi ojek pangkalan. Pengemudi ojek pangkalan menganggap bahwa jasa transportasi ojek online Go-Jek telah mengambil hak pengemudi ojek pangkalan yang mengambil penumpang di wilayah ojek pangkalan. Oleh karena itu, para pengemudi ojek pangkalan berharap adanya saling pengertian atau kompromi dari pihak perusahaan Go-Jek untuk memahami dan memberitahukan kepada pengemudi ojek online Go-Jek untuk tidak mengambil penumpang di wilayah ojek pangkalan, sehingga perselisihan yang sering terjadi dapat diatasi. 


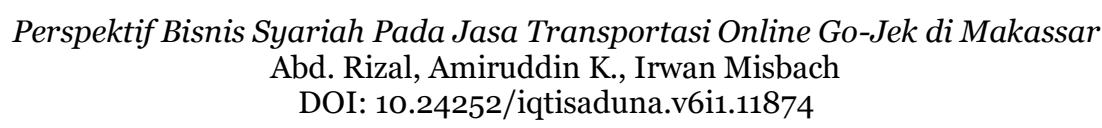

Dalam pandangan pengguna sebagai pengemudi ojek online, kehadiran perusahaan Go-Jek berdampak positif dalam hal penyediaan lapangan kerja. Kehadiran perusahaan GoJek membuka kesempatan kerja bagi masyarakat, sedangkan dalam pandangan pengguna sebagai konsumen atau penumpang jasa angkutan online Go-Jek, kehadiran ojek online GoJek memberikan banyak manfaat dan kemudahan, seperti lebih efisien, hemat waktu dan tenaga, mudah dan praktis, aman dan terpercaya, tarif murah, banyak diskon dan promo, dapat dibayar dengan cara tunai dan non tunai, jumlah pengemudi yang banyak dan memiliki berbagai jenis layanan.

Dalam perspektif bisnis syariah pada jasa transportasi online Go-Jek, perusahaan jasa transportasi online Go-Jek dinilai telah memenuhi dan menjalankan konsep bisnis syariah yang terdiri dari prinsip dasar bisnis syariah, etika bisnis syariah dan tujuan bisnis syariah.

\section{DAFTAR PUSTAKA}

Abdullah, Ma'ruf. 2014. Manajemen Bisnis Syariah. Yogyakarta: Aswaja Pressindo.

Aedi, Hasan. 2011. Etika Bisnis Islam. Bandung: Alfabeta.

Ali, Mohammad Daud. 200o. Hukum Islam Pengantar Ilmu Hukum dan Tata Hukum Islam

Di Indonesia. Jakarta: PT Raja Grafindo Persada.

Amiruddin dan Zainal Asikin. 2004. Pengantar Metode Penelitian Hukum. Jakarta: Rajawali pers.

Anwar, Ahsani Amalia. 2017. "Online vs Konvensional: Keunggulan dan Konflik antar Moda Transportasi di Kota Makassar”. Etnosia: Jurnal Etnografi Indonesia 2 (2): 220-246.

Arikunto, Suharsimi. 2003. Prosedur Penelitian; Suatu Pendekatan Praktek. Jakarta: Renika Cipta.

Asmuni dan Siti Mujiatun. 2016. Bisnis Syariah. Medan: Perdana Mulya Sarana.

Aula, Muhammad Syakir. 2004. Asuransi Syariah Life and General: Konsep dan Sistim Operasional. Jakarta: Gema Insani Press.

Aziah, Ayu dan Popon Rabia Adawia. 2018. "Perkembangan Industri Transportasi Online di Era Inovasi Discruptif (Studi Kasus PT Gojek Indonesia”. Cakrawala-Jurnal Humaniora 18 (2): 149-156.

Basri, Hasnil. 2002. Hukum Pengangkutan. Medan: Kelompok Studi Hukum Fakultas Hukum US.

Binhadi, dkk. 2011. Pedoman Umum Good Governance Bisnis Syariah. Jakarta: Komite Nasional Kebijakan Governance.

Bungin, M Burhan. 2011. Penelitian Kualitatif. Jakarta: Kencana Prenada Media Group.

Emzir. 2011. Analisis Data: Metodologi Penelitian Kualitatif. Jakarta: Rajawali Pers.

Hadi, Surtrisno. 2000. Metodologi Reseach. Jakarta: UGM Press.

Hafidhuddin, Didin dan Hendry Tanjung. 2003. Manajemen Syariah dalam Praktik. Jakarta: Gema Insani. 
Hoetomo. 2005. Kamus Lengkap Bahasa Indonesia. Surabaya: Mitra Pelajar.

Kementerian Agama RI. 2013. Al-Qur'an The Great Miracle. Solo: PT. Tiga Serangkai Pustaka Mandiri.

Maidin, Muhammad Sabir. 2012. Ingkar Sunnah/Hadis I: dalam Perspektif Historis. Makassar: Alauddin University Press.

Mardalis. 2004. Metode Penelitian: Suatu Pendekatan. Jakarta: Bumi Aksara.

Moleong, Lexi J. 2010. Metodologi Penelitian Kualitatif. Bandung: Remaja Rosdakarya.

Misbach, Irwan. 2017. “Al-Idarah”. Al Idarah Volume 5: 33 - 44

Nazir. 2003. Metode Penelitian. Bandung: Ghalia Indonesia.

Nawawi, Ismail. 2012. Fiqih Muamalah: Klasik dan Kontemporer. Bogor: Ghalia Indonesia.

Norvadewi. 2015. "Bisnis dalam Perspektif Islam”. Al-Tijary 1 (1): 35-45.

Sakirman. 2016. "Urgensi Maslahah Dalam Konsep Ekonomi Syariah". PALITA: Journal of Social-Religi Research 1 (1):17-28.

Salim, Syahrun. 2012. Metode Penelitian Kualitatif. Bandung: Citapustaka Media.

Sanjaya, Wina. 2014. Penelitian pendidikan. Jakarta: Kencana.

Shobirin. 2015. "Jual Beli dalam Pandangan Islam”. BISNIS 3 (2): 240-261.

Soekanto dan Mamudji. 2009. Penelitian Hukum Normatif: Suatu Tinjauan Singkat. Jakarta: Rajawali Press.

Sugiyono. 2008. Memahami Penelitian Kualitatif. Bandung: Alfabeta.

Syafe'i, Rachmat. 2015. Ilmu Ushul Fiqih. Bandung: Pustaka Setia.

Tarmizi, Erwandi. 2015. Harta Haram Muamalat Kontemporer. Bogor: PT. Berkat Mulia Insani.

Republik Indonesia. 2014. Undang-Undang Republik Indonesia Nomor 74 tentang Angkutan Jalan.

Republik Indonesia. 2019. Keputusan Menteri Perhubungan Republik Indonesia Nomor KP 343 tahun 2019 tentang pedoman perhitungan biaya jasa.

Yusuf, A Musri. 2014. Metode Penelitian Kuantitatif, kualitatif dan Penelitian Gabungan. Jakarta: Fajar Interpratama Mandiri. 